\title{
STUDI KASUS KOMPRES HANGAT DALAM MENURUNKAN SUHU TUBUH PADA ANAK DENGAN DEMAM THYPOID DI RUMAH SAKIT TK II PUTRI HIJAU MEDAN
}

\author{
Mawar Saron Simangunsong ${ }^{1 *}$, Syaiful $^{2}$, Evamona Sinuraya ${ }^{3}$
}

${ }^{1}$ Mahasiwa Program Studi Keperawatan Akper Kesdam I/BB Medan

Email: saronmawar75@gmail.com

2Dosen Program Studi Keperawatan Akper Kesdam I/BB Medan

Email: syaifulsirin@yahoo.com

${ }^{3}$ Dosen Program Studi Keperawatan Akper Kesdam I/BB Medan

\section{ABSTRACT: A CASE STUDY OF WARM COMPRESS TO REDUCE BODY TEMPERATURE IN CHILDREN WITH THYPOID FEVER IN TK II PUTRI GREEN HOSPITAL, MEDAN}

Background : Typhoid fever is an acute infectious disease of the small intestine caused by salmonella typhosa bacteria and its only found in humans. Based on World Health Organization (2018) typhoid fever is life-threatening fever disease. The case fatality of typhoid fever is $10-30 \%$, decreasing to $1-4 \%$ with appropriate therapy. Young children are at greatest risk of common symptoms of fever, shivering, and abdominal pain. It is estimated that there are 11-21 million cases of typhoid fever and about 128,000-161,000 deaths per year. The fever could be reduced by providing the warm compress.

Purpose: The purpose of the study was to find out the description of warm compress on decreasing the body temperature in children with typhoid fever at Tk II Putri Hijau Hospital Medan in 2021.

Method: The method used descriptive case study design by involving the stages of nursing process: assessment, diagnosis, intervention, implementation, and evaluation that implemented on 2 patients with typhoid fever.

Result: After the nursing care processed in two patients, the result showed that the fever could be resolved by providing the warm compres to the patient's axilla. Body temperature when admitted to the hospital in the first patient was from $38^{\circ} \mathrm{C}$ to $36.5^{\circ} \mathrm{C}$ and in the second patient from $38.5^{\circ} \mathrm{C}$ to $36.5^{\circ} \mathrm{C}$.

Conclusion: The conclusion after nursing care was implemented on the first and second patient that the warm compress was effective in decreasing body temperature.

Keywords : Typhoid Fever, Body Temperature, Warm Compress. 
INTISARI: STUDI KASUS KOMPRES HANGAT DALAM MENURUNKAN SUHU TUBUH PADA ANAK DENGAN DEMAM THYPOID DI RUMAH SAKIT TK II PUTRI HIJAU MEDAN

Latar Belakang Demam typhoid merupakan penyakit infeksi akut pada usus halus yang disebabkan oleh Salmonella typhosa dan hanya terdapat pada manusia. Berdasarkan data World Health Organization (2018), demam typhoid adalah penyakit demam akut yang mengancam jiwa. Kasus fatalitas tipus demam $10-30 \%$, turun menjadi 1-4\% jika sesuai terapi. Anak-anak kecil berada pada resiko terbesar dengan gejala umum demam, menggigil, dan rasa sakit diperut. Diperkirakan 11-21 juta kasus demam thyfoid dan sekitar 128.000-161.000 kematian setiap tahunnya. Demam tersebut dapat berkurang dengan pemberian tindakan kompres hangat. Tujuan: Tujuan penelitian ini adalah untuk mengetahui gambaran tentang Kompres Hangat Dalam Menurunkan Suhu Tubuh Pada Anak Dengan Demam Thypoid Di Rumah Sakit Tk II Putri Hijau Medan 2021.

Metode Penelitian ini merupakan penelitian deskriptif dalam rancangan studi kasus yang terdiri dari tahapan proses keperawatan: pengkajian, diagnosa keperawatan, intervensi keperawatan, implementasi keperawatan, dan evaluasi keperawatan terhadap 2 pasien penderita demam thypoid.

Hasil Setelah dilakukan proses asuhan keperawatan terhadap 2 pasien diperoleh hasil demam dapat teratasi dengan pemberian kompres hangat pada aksila pasien. Suhu tubuh saat masuk RS pada pasien 1 yaitu dari $38^{\circ} \mathrm{C}$ menjadi $36,5^{\circ} \mathrm{C}$ dan pada pasien 2 dari $38,5^{\circ} \mathrm{C}$ menjadi $36,5^{\circ} \mathrm{C}$. Kesimpulan Setelah dilakukan tindakan keperawatan terhadap pasien 1 dan pasien 2, dengan pemberian kompres hangat efektif dalam menurunkan suhu tubuh.

Kata kunci : Demam Thypoid, Suhu Tubuh, Kompres Hangat

\section{PENDAHULUAN}

Demam typhoid (typhus abdominalis) merupakan penyakit infeksi akut pada usus halus yang disebabkan oleh Salmonella typhosa dan hanya terdapat pada manusia (Marni, 2016). Demam thypoid (enteric fever) adalah penyakit infeksi akut yang biasanya mengenai saluran pencernaan dengan gejala demam yang lebih dari satu minggu, gangguan pada pencernaan, dan gangguan kesadaran (Lestari, 2016).

Berdasarkan data

World

Health Organization, demam typhoid adalah penyakit demam akut yang mengancam jiwa. Tanpa pengobatan, kasus fatalitas tipus demam 10-30\%, turun menjadi 1-4\% jika sesuai terapi. Anak-anak kecil berada pada resiko terbesar dengan gejala umum demam, menggigil, dan rasa sakit diperut. Diperkirakan 11-21 juta kasus demam tifoid dan sekitar 128.000-161.000 kematian setiap tahun (WHO, 2018).

Menurut Kemenkes RI 2018, tifoid merupakan salah satu penyakit endemis yang ada di Indonesia, mayoritas mengenai anak usia sekolah dan kelompok usia produktif, penyakit ini menyebabkan angka absensi yang tinggi, rata-rata perlu waktu 7-14 hari untuk perawatan apabila seseorang terkena Tifoid. Apabila pengobatan yang dilakukan tidak tuntas maka dapat menyebabkan terjadinya karier yang kemudian menjadi sumber penularan bagi orang lain.

Berdasarkan profil kesehatan Deli Serdang tahun 2016, demam typoid 
termasuk dalam salah satu dari sepuluh penyakit terbesar di Kabupaten tersebut. Jumlah penderita rawat inap pada tahun 2015 sebanyak 522 orang dan di tahun 2016 meningkat menjadi 605 orang. Sedangkan penderita yang dirawat jalan sebanyak 411 orang.

Peningkatan suhu tubuh yang tidak ditangani dapat menyebabkan dehidrasi yang akan mengganggu keseimbangan elektrolit serta menyebabkan kejang. Kejang yang berulang akan mengakibatkan kerusakan pada sel otak yang akan menyebabkan gangguan tingkah laku, serta demam. Demam mengacu pada peningkatan suhu tubuh sebagai akibat dari infeksi atau peradangan sebagai respon terhadap invasi mikroba, sel-sel darah putih tertentu mengeluarkan suatu zat kimia yang dikenal sebagai pirogen endogen yang memiliki banyak efek untuk melawan infeksi (Elon \& Uly, 2018)

Sehubungan dengan hal tersebut, maka penanganan demam perlu dilakukan dengan tindakan farmakologis dan nonfarmakologis. Tindakan farmakologis yaitu pemberian obat sebagai penurun demam atau disebut dengan antipiretik. Sedangkan tindakan non farmakologis tindakan penurunan demam dengan menggunakan terapi fisik seperti menempatkan anak di ruang bersuhu dan bersirkulasi baik, memberikan pakaian yang longgar, dan memberikan kompres (Kania, 2007) dalam (Zurimi, 2019).

Kompres adalah salah satu metode fisik untuk menurunkan suhu tubuh bila mengalami demam. Salah satu metode kompres yang sering digunakan adalah pemberian kompres hangat yaitu mengelap sekujur tubuh dengan air hangat menggunakan waslap, dan dengan mengompres pada bagian tubuh tertentu yang memiliki pembuluh darah besar (Pangaribuan, 2018)

Menurut hasil penelitian dari Elon (2018), bahwa suhu tubuh pasien sebelum dilakukan tindakan kompres hangat pada temporal lobe adalah $38,14{ }^{\circ} \mathrm{C}$ yang berarti demam sedang dan sesudah diberikan tindakan kompres hangat pada temporal mengalami penurunan menjadi $37,09^{\circ} \mathrm{C}$ yang dikategorikan sebagai suhu tubuh normal. Peneliti juga melakukan kompres hangat pada abdomen dan sebelum dilakukan tindakan, suhu tubuh $38,13{ }^{\circ} \mathrm{C}$ yang berarti demam sedang dan sesudah diberikan tindakan kompres hangat pada abdomen, mengalami penurunan menjadi $37,65^{\circ} \mathrm{C}$ yang dikategorikan sebagai demam ringan. Hasil tersebut memperlihatkan bahwa pemberian kompres hangat pada temporal lobe dan abdomen tersebut sama-sama efektif dalam menurunkan suhu tubuh.

Sedangkan hasil penelitian dari Ayu (2015), teknik pemberian kompres hangat pada daerah aksila lebih efektif terhadap penurunan suhu tubuh dibandingkan dengan teknik pemberian kompres hangat pada dahi pada pasien demam. Hal ini dapat dilihat dari rerata derajat penurunan suhu tubuh sebelum dan sesudah dilakukan kompres hangat pada daerah aksila pada pasien demam yaitu $0,247^{\circ} \mathrm{C}$, dan rerata derajat penurunan suhu tubuh sebelum dan sesudah dilakukan kompres hangat pada daerah dahi yaitu sebesar 0,111 ${ }^{\circ} \mathrm{C}$.

\section{METODE PENELITIAN}

\begin{tabular}{lrr}
\multicolumn{1}{c}{ Penelitian ini } & merupakan \\
penelitian deskriptif & dengan \\
rancangan studi kasus penurunan suhu & \\
tubuh dengan teknik kompres hangat & hemalui pendekatan & proses
\end{tabular}


keperawatan yang dilakukan peneliti. Subyek penelitian yang digunakan adalah 2 pasien dengan 1 kasus dengan masalah keperawatan yang sama.

Studi kasus penurunan suhu tubuh dengan teknik kompres hangat pada pasien hipertensi dengan kriteria inklusi: bersedia menjadi subyek penelitian, pasien anak yang mengalami peningkatan suhu diatas $37,5^{\circ} \mathrm{C}$. Anak dengan demam tifoid tanpa komplikasi. Anak dengan jenis kelamin perempuan/laki-laki dengan usia 5-14 tahun. Kriteria eksklusi: klien menolak menjadi subjek penelitian, klien yang mengalami komplikasi penyakit lain. Fokus Studi dalam penelitian ini yaitu penurunan suhu tubuh dengan teknik kompres hangat dengan dua pasien dalam kasus yang sama. Laporan ini penulis membatasi pada Asuhan Keperawatan dengan Gangguan Sistem Pencernaan di Rumah Sakit TK II Putri Hijau Medan lama sejak pasien pertama kali masuk Rumah Sakit sampai pulang dan atau yang dirawat minimal 3 hari. Penelitian akan dilakukan pada bulan Desember 2020 sampai dengan Juni 2021. Alat atau instrument pengumpulan data dalam wawancara menggunakan format pengkajian Asuhan Keperawatan Anak sedangkan dalam observasi menggunakan alatalat seperti termometer. Metode Pengumpulan data dalam karya tulis studi kasus ini adalah dengan menggunakan instrument Biofisiologis, Observasi, Wawancara, dan Kuesioner

\section{HASIL PENELITIAN DAN PEMBAHASAN}

Hasil Penelitian

a. Identitas Pasien

Tabel 1 Identitas Pasien

\begin{tabular}{llll}
\hline No & Identitas Pasien & \multicolumn{1}{c}{ Kasus I } & \multicolumn{1}{c}{ Kasus II } \\
\hline 1. & Nama & An. M & An. A \\
2. & Umur & 6 Tahun & 10 Tahun \\
3. & Jenis Kelamin & Laki-laki & Laki-laki \\
4. & Pendidikan & SD & SD \\
5. & Perkerjaan & Sekolah & Sekolah \\
6. & Status & Belum Menikah & Belum menikah \\
7. & Agama & Islam & Islam \\
8. & Suku/Bangsa & Indonesia & Indonesia \\
9. & Diagnosa Medis & Demam Thypoid & Demam thypoid \\
10 & Alamat & Jl.Pancing1No.51 Lingk.IX & Jl. Asrama TNI-AD Cengkeh \\
11. & Sumber Informasi & Auto anamnesa & Auto Anamnesa \\
12 & Tanggal Masuk RS & 20 April 2021, Pukul & 21 Maret 2021, Pukul : 09.00 \\
& & 21.00 WIB & WIB \\
13. & Tanggal dan jam & 21 April 2021, Pukul : & 21 April 2021, Pukul : 14.00 \\
& pengkajian & 15.00 WIB & WIB \\
\hline
\end{tabular}

Berdasarkan Tabel 1 di atas didapatkan dari kedua responden mempunyai diagnosa medis yang sama yaitu Demam Thypoid dan jenis kelamin yang sama yaitu laki-laki. Pada kasus I berumur 6 Tahun sedangkan pada kasus II berumur 10 Tahun. 
Data Fokus

Tabel 2 Data Fokus

\begin{tabular}{|c|c|c|}
\hline Data Fokus & Kasus I & Kasus II \\
\hline $\begin{array}{l}\text { Keluhan utama saat } \\
\text { pengkajian }\end{array}$ & $\begin{array}{l}\text { Klien mengatakan demam } \\
\text { sejak } \pm \text { hhari yang lalu, } \\
\text { demam naik pada sore dan } \\
\text { malam hari, terasa nyeri } \\
\text { pada kepala. }\end{array}$ & $\begin{array}{l}\text { Klien mengatakan demam } \\
\text { tinggi } \pm 6 \text { hari pada sore dan } \\
\text { malam hari, disertai } \\
\text { menggigil, nyeri ulu hati dan } \\
\text { kepala. }\end{array}$ \\
\hline $\begin{array}{l}\text { Keluhan Utama saat } \\
\text { Pengkajian }\end{array}$ & $\begin{array}{l}\text { Klien mengatakan mual } \\
\text { muntah, terasa nyeri pada } \\
\text { kepala dan pusing, sering } \\
\text { jajan disembarang } \\
\text { tempat.BB turun } 1 \mathrm{~kg} \text {. TB: } \\
91 \mathrm{~cm}, \mathrm{BB}: 21 \mathrm{~kg} \text {. }\end{array}$ & $\begin{array}{l}\text { Klien mengatakan mual dan } \\
\text { muntah, nyeri pada ulu hati } \\
\text { dan kepala terasa pusing } \\
\text { sering lupa mencuci tangan } \\
\text { sebelum makan. BB turun } 1 \\
\text { kg TB: } 89 \mathrm{~cm}, \mathrm{BB}: 19 \mathrm{~kg} \text {. }\end{array}$ \\
\hline Faktor Pencetus & $\begin{array}{l}\text { Gaya hidup yang tidak sehat } \\
\text { dan aktivitas saat bermain }\end{array}$ & $\begin{array}{l}\text { Personal hygiene yang buruk } \\
\text { dan aktivitas saat bermain }\end{array}$ \\
\hline $\begin{array}{l}\text { Riwayat } \\
\text { sekarang }\end{array}$ & Demam Thypoid & Demam Thypoid \\
\hline $\begin{array}{l}\text { Riwayat } \\
\text { yang lalu }\end{array}$ & $\begin{array}{l}\text { Klien tidak mempunyai } \\
\text { riwayat penyakit }\end{array}$ & $\begin{array}{l}\text { Klien tidak mempunyai } \\
\text { riwayat penyakit }\end{array}$ \\
\hline $\begin{array}{l}\text { Riwayat } \\
\text { keluarga }\end{array}$ & $\begin{array}{l}\text { Tidak ada keluarga yang } \\
\text { menderita penyakit demam } \\
\text { tifoid. }\end{array}$ & $\begin{array}{l}\text { Tidak ada keluarga yang } \\
\text { menderita penyakit demam } \\
\text { tifoid }\end{array}$ \\
\hline
\end{tabular}

Berdasarkan Tabel 2 di atas ditemukan keluhan utama dan riwayat sakit terhadap kasus I yaitu ibu klien mengatakan demam sejak \pm 5 hari yang lalu, demam naik pada sore dan malam hari, klien mengatakan mualmuntah ketika makan dan terasa nyeri pada kepala, anak sering jajan disembarang tempat. Sedangkan kasus II yaitu ibu klien mengatakan demam

\section{b. Analisa Data}

Berdasarkan hasil analisa data bahwa pada kasus 1 mengalami hipertermi berhubungan dengan infeksi kuman salmonella thypi reaksi tinggi \pm 6 hari pada sore dan malam hari disertai menggigil, klien mengatakan mual dan muntah ketika makan, terasa nyeri pada ulu hati dan kepala terasa pusing, klien mengatakan sering lupa mencuci tangan sebelum makan. Kasus 1 dan kasus 2 sama-sama memiliki penyakit pada sistem pencernaan.

inflamasi sistemik ditandai dengan ibu klien mengatakan anaknya demam naik pada saat malam hari, ibu klien mengatakan anaknya demam \pm 5 hari, ibu klien mengatakan badannya menggigil jika suhu 
tubuhnya meningkat, klien tampak lemas, Pols : $80 \mathrm{x} /$ menit, RR : 20 $\mathrm{x} /$ menit, dan Temp : $38^{\circ} \mathrm{C}$ dan hasil pemeriksaan widal $0: 1 / 3201 / 180$ $1 / 1601 / 80 \mathrm{H}: 1 / 601 / 801 / 3201 / 80$.

c. Diagnosa Keperawatan

\begin{tabular}{|c|c|}
\hline Kasus 1 & Kasus 2 \\
\hline $\begin{array}{l}\text { Hipertermi berhubungan dengan } \\
\text { dengan infeksi kuman salmonella thypi } \\
\text { reaksi inflamasi sistemik ditandai } \\
\text { dengan lbu mengatakan anak demam } \\
\text { tinggi sejak } \pm 5 \text { hari yang lalu, lbu } \\
\text { mengatakan demam naik saat malam } \\
\text { hari, ibu mengatakan anak merasa } \\
\text { pusing dan nyeri pada kepala, badan } \\
\text { klien teraba panas, Temp : } 38^{\circ} \mathrm{C} \text {, klien } \\
\text { tampak lemah, Hasil pemeriksaan widal } \\
0: 1 / 3201 / 1801 / 1601 / 80, \mathrm{H}: 1 / 60 \\
1 / 801 / 3201 / 80 \text {, leukosit } 23,238 \mathrm{~mm}^{3} \text {. }\end{array}$ & $\begin{array}{l}\text { Hipertermi berhubungan dengan infeksi } \\
\text { kuman salmonella thypi reaksi inflamasi } \\
\text { sistemik ditandai dengan lbu mengatakan } \\
\text { anaknya demam } \pm 6 \text { hari naik turun, Ibu } \\
\text { mengatakan badan anaknya menggigil } \\
\text { jika suhu tubuh meningkat, Ibu } \\
\text { mengatakan badan anaknya lemas, klien } \\
\text { tampak lemas, badan teraba panas, } \\
\text { Temp : } 38,5^{\circ} \mathrm{C} \text {, RR : } 20 \times / \mathrm{i} \text {, Pols : } 80 \times / \mathrm{l} \text {, } \\
\text { Hasil pemeriksaan widal : O : } 1 / 801 / 80 \\
1 / 1601 / 160 \mathrm{H}: 1 / 3201 / 801 / 1601 / 160 \text {, } \\
\text { Leukosit : } 5.100 \mathrm{~mm}^{3} \text {, Trombosit : } \\
221.000 \text {. }\end{array}$ \\
\hline
\end{tabular}

\section{PEMBAHASAN}

Pada penelitian ini, peneliti akan membahas Asuhan Keperawatan pada pasien anak dengan Demam Thypoid hipertermi Rumah Sakit TK II Putri Hijau Medan. Penelitian ini telah dilakukan pada tanggal 21 April 2021 sampai 24 April 2021 untuk kasus 1 dan 2 dalam hal ini pembahasan yang dimaksud adalah membandingkan antara tujuan kasus dan tinjauan pustaka yang disajikan untuk menjawab tujuan khusus dari penelitian. Dimana setiap temuan perbedaan diuraikan dengan konsep dan pembahasan disusun dengan cara khusus.

Peneliti melakukan penelitian terhadap dua kasus yang sama-sama memiliki penyakit Demam Thypoid Rumah Sakit TK II Putri Hijau Medan dengan lima tahap sesuai dengan proses keperawatan yang dikemukakan oleh American Nurse Association (ANA) yaitu pengkajian, diagnosa keperawatan, perencanaan,

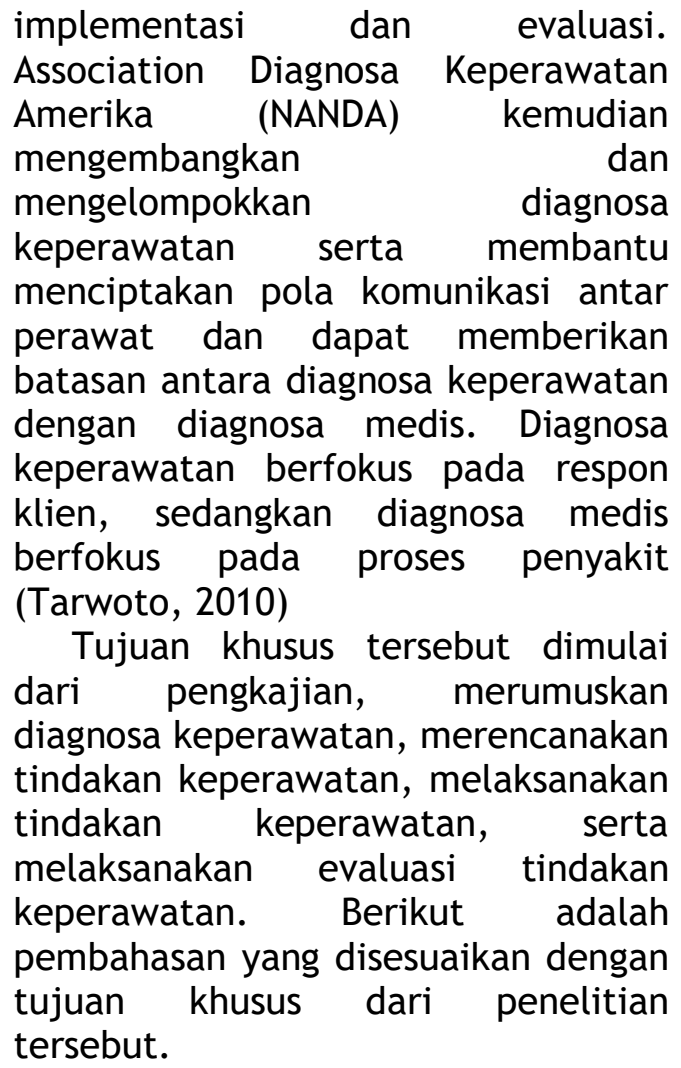

implementasi dan evaluasi. Association Diagnosa Keperawatan Amerika (NANDA) kemudian mengembangkan dan mengelompokkan diagnosa keperawatan serta membantu menciptakan pola komunikasi antar perawat dan dapat memberikan batasan antara diagnosa keperawatan dengan diagnosa medis. Diagnosa keperawatan berfokus pada respon klien, sedangkan diagnosa medis berfokus pada proses penyakit arwoto, 2010) dari pengkajian, merumuskan diagnosa keperawatan, merencanakan tindakan keperawatan, melaksanakan tindakan keperawatan, serta melaksanakan evaluasi tindakan keperawatan. Berikut adalah pembahasan yang disesuaikan dengan tersebut. 


\section{Pengkajian}

Berdasarkan tabel pengkajian didapatkan dari kedua kasus mempunyai diagnosa medis yang sama didasarkan pada adanya demam naik pada sore hari, mual, muntah, anoreksia, pusing dan nyeri kepala. Hal ini sesuai dengan teori yang dikemukakan oleh Yatnita (2017), bahwa demam terjadi terutama sore dan malam hari, sakit kepala, nyeri otot, anoreksia, mual, muntah obstipasi atau diare. Demam merupakan keluhan dan gejala klinis terpenting yang timbul pada semua penderita demam thypoid, demam dapat muncul secara tiba-tiba dalam satu hari menjadi parah dengan gejala menyerupai septisemia oleh karena S. Thypi sehingga kedua kasus tersebut memiliki diagnosa Demam Thypoid. Jadi demam thypoid dapat diketahui dengan terjadinya demam secara bertahap dan naik pada sore/malam hari, mual, muntah, anoreksia, sakit kepala dan diare.

Berdasarkan tabel pengkajian didapatkan kedua kasus memiliki perbedaan secara klinis yaitu pada kasus 1 memiliki gejala klinis muntah dan diare sedangkan pada kasus 2 tidak memiliki gejala klinis tersebut. Hal ini sesuai dengan teori Ahmad (2016) bahwa anak laki-laki lebih sering bermain di luar rumah daripada di dalam rumah seperti bermain sepak bola dan kegiatan lain yang bisa mengakibatkan anak lebih mudah terserang penyakit, berbeda dengan anak perempuan yang kebanyakan bermain di dalam rumah.

Berdasarkan tabel pengkajian didapatkan kedua kasus tidak memiliki kesamaan yaitu pada kasus 1 berumur 6 tahun dan kasus 2 berumur 10 tahun dengan jenis kelamin yang sama yaitu laki-laki. Menurut teori Ni dan Diah (2017) bahwa penderita demam thypoid anak yang paling banyak adalah laki-laki, hal ini sesuai dengan penelitian sebelumnya bahwa laki-laki lebih rentan terkena demam thypoid dikaitkan dengan aktivitas laki-laki yang lebih sering di luar rumah yang memungkinkan laki-laki beresiko lebih besar terinfeksi Salmonella thypi dibandingkan perempuan sehingga dapat dikatakan jenis kelamin juga dapat mempengaruhi terjadinya demam thypoid.

Berdasarkan tabel pengkajian kedua kasus tidak memiliki umur yang sama yakni kasus 1 berumur 6 tahun dan kasus 2 berumur 10 tahun. Menurut Galuh (2017) prevalensi demam thypoid paling tinggi pada anak usia 3-19 tahun karena pada usia tersebut orang-orang cenderung memiliki aktivitas fisik yang banyak, dan kurang memperhatikan pola makannya, akibatnya mereka cenderung lebih memilih makan di luar atau jajan disembarang tempat yang kurang memperhatikan higienitas.

Berdasarkan tabel pengkajian didapatkan bahwa kedua kasus memiliki suhu tubuh yang berbeda yaitu pada kasus 1 dengan suhu $38^{\circ} \mathrm{C}$ sedangkan pada kasus 2 dengan suhu $38,5^{\circ} \mathrm{C}$. Hal ini sesuai dengan teori menurut $\mathrm{Ni}$ dan Diah (2017) bahwa peningkatan suhu tubuh karena adanya zat yang dapat menyebabkan efek perangsangan terhadap pusat pengaturan suhu yang bahannya disebut pirogen. Pirogen dapat berasal dari bakteri Salmonella Thypi. Bakteri akan difagositosis oleh makrofag. Makrofag mencerna hasil pemecahan bakteri dan melepaskan zat interleukin-1, yang disebut pirogen endogen. Interleukin ketika sampai di hipotalamus akan menimbulkan demam dengan cara meningkatkan suhu tubuh dalam waktu 8-10 menit. 
Interleukin-1 juga menginduksi pembentukan prostaglandin E2 yang bekerja di hipotalamus untuk membangkitkan reaksi demam.

\section{Diagnosa Keperawatan}

Berdasarkan diagnosa keperawatan didapatkan kedua kasus yaitu kasus 1 dan kasus 2 memiliki diagnosa medis serta diagnosa keperawatan yang sama yaitu Demam Thypoid dengan diagnosa keperawatan peningkatan suhu tubuh/hipertermi. Dimana data yang digunakan dalam menegakkan diagnosa keperawatan lebih difokuskan pada pemeriksaan kedua kasus, dan didapatkan hasil pada kasus 1 dan kasus 2 sama-sama mempunyai 3 diagnosa keperawatan.

Secara teoritis yang dikemukakan oleh Riyadi, (2010) terdapat 4 diagnosa keperawatan pada demam thypoid yaitu :1). Hipertermia berhubungan dengan proses infeksi salmonella thyposa, 2). Resiko defisit volume cairan berhubungan dengan pemasukan yang kurang, mual, muntah/pengeluaran yang berlebihan, diare, panas tubuh, 3). Resiko ketidakseimbangan nutrisi kurang dari kebutuhan tubuh berhubungan dengan intake kurang akibat mual, muntah, anoreksia, atau output yang berlebihan akibat diare, 4). Gangguan pola defekasi : diare berhubungan dengan proses peradangan pada dinding usus halus.

Namun pada pembahasan ini hanya akan dibahas 1 masalah keperawatan yang sama yakni kasus 1 dengan hipertermi berhubungan dengan kuman masuk kedalam tubuh menyebabkan proses infeksi sehingga menyerang pusat panas dihipotalamus ditandai dengan Ibu mengatakan anak demam tinggi sejak 5 hari yang lalu, Ibu mengatakan demam naik saat malam hari, ibu mengatakan anak merasa pusing dan nyeri pada kepala, badan klien teraba panas, Temp : $38^{\circ}$ C, klien tampak lemas, Pols : 80 $\mathrm{x} /$ menit, RR : $20 \mathrm{x} /$ menit, dan hasil pemeriksaan widal $0: 1 / 3201 / 180$ 1/160 1/80 H : 1/60 1/80 1/320 1/80 dan pada kasus 2 hipertermi berhubungan dengan respon inflamasi sistemik ditandai dengan ibu klien mengatakan anak demam \pm 6 hari naik turun, ibu mengatakan badan anaknya menggigil jika suhu tubuh meningkat, ibu mengatakan badan anknya lemas, Temp : $38,5^{\circ} \mathrm{C}$, RR : $20 \mathrm{x} / \mathrm{l}$, Pols : 80 $\mathrm{x} / \mathrm{I}$, Hasil pemeriksaan widal: $0: 1 / 80$ $1 / 801 / 1601 / 160 \mathrm{H}: 1 / 3201 / 80$ $1 / 1601 / 160$, Leukosit $5100 / \mathrm{mm}^{3}$, trombosit : 221.000 .

\section{Rencana Keperawatan}

Berdasarkan tabel intervensi didapatkan hasil dari kedua kasus mempunyai rencana tindakan keperawatan yang sama. Adapun intervensi keperwatan yang dilakukan yaitu : 1). Monitor suhu sesering mungkin, 2). Anjurkan banyak minum air hangat, 3). Anjurkan klien memakai pakaian tipis dan menyerap keringat, 4). Kolaborasi dalam pemberian pengobatan untuk mengatasi penyebab demam, 5). Lakukan kompres hangat pada pasien, 6). Monitor TTV pasien. Tindakan keperawatan yang dilakukan untuk kedua kasus ini sesuai dengan rencana tindakan menurut Suratun (2014) yaitu observasi keadaan umum pasien, observasi tanda-tanda vital, anjurkan pasien untuk banyak minum dan banyak istirahat, anjurkan pasien untuk memakai pakaian yang tipis dan menyerap keringat, beri kompres hangat di aksila.

\section{Evaluasi Keperawatan}

Setelah dilakukan tindakan terhadap pelaksanaan asuhan keperawatan pada kasus 1 dan kasus 2, maka tahap 
evaluasi beberapa masalah teratasi dihari keempat. Selama tiga hari dilakukan perawatan pada kasus 1 (mulai tanggal 22 Mei s/d 24 Mei 2021) dan selama tiga hari dilakukan perawatan pada kasus 2 (mulai tanggal 22 Mei s/d 24 Mei 2021), maka dapat dievaluasi bahwa : Kasus 1 dan 2 dengan masalah hipertermi dikatakan teratasi karena dari hasil observasi dari perawat, yaitu: Suhu tubuh normal $\left(36,5^{\circ} \mathrm{C}\right)$, Mukosa lidah tampak bersih dan bibir lembab, turgor kulit baik <2 detik, tidak terdapat perubahan pada warna kulit, therapy medis yang diberikan : novalgin, ranitidine, ondancentron, ceftriaxon. Dari hasil observasi klien dapat disimpulkan bahwa masalah hipertermi teratasi.

\section{Kesimpulan dan Saran \\ Kesimpulan}

Dalam pengkajian antara kasus 1 (An. M) dan kasus 2 (An. A) didapatkan data senjang bahwa pada pasien 1 adanya peningkatan suhu tubuh yaitu $38{ }^{\circ} \mathrm{C}$, muntah, pusing dan nyeri kepala, sedangkan pada pasien 2 adanya peningkatan suhu tubuh yaitu $38,5^{\circ} \mathrm{C}$, pusing dan nyeri kepala dan ulu hati, masing-masing klien memiliki 3 diagnosa yang sama. Kemudian dibuat perencanaan pada setiap diagnosa. Setelah dibuat perencanaan kemudian perawat menerapkannya. Setelah dilakukan tindakan keperawatan kasus 1 dan kasus 2, maka dapat disimpulkan bahwa peningkatan suhu tubuh dapat teratasi.

\section{Saran}

a. Bagi Rumah Sakit

Hendaknya Rumah Sakit menyusun kebijakan terlebih dibagian pelayanan kepada pasien (masyarakat) yang membutuhkan pertolongan segera. b. Pengembangan Ilmu dan Teknologi Keperawatan Hendaknya hasil penelitian ini dapat digunakan sebagai masuknn bagi peneliti lain untuk melakuk 61 penelitian yang lebih mendalam lagi tentang Studi Kasus Penurunan Suhu Tubuh Pada Anak Dengan Demam Thypoid.

c. Pasien dan Keluarga Hendaknya dapat meningkatkan derajat kesehatan dan perawatan pasien setelah pulang dari Rumah Sakit (home care).

\section{DAFTAR PUSTAKA}

Ahmad Susanto. (2016). Teori Belajar dan Pembelajaran. Jakarta: Prenada Media Group

Ayu, dkk.(2015). Kompres Air Hangat Pada Daerah Aksila Dan Dahi Terhadap Penurunan Suhu Tubuh Pada Pasien Demam. Jurnal Ners Dan Kebidanan Indonesia ISSN 2354-7642.3 (1). 10-14

https://www.researchgate.ne $\underline{\mathrm{t}}$

Elon,Y\&Uly, S.(2018). Tindakan Kompres Hangat Pada Temporal Lobe Dan Abdomen Terhadap Reaksi Suhu Tubuh Pasien Dengan Typhoid Fever. Jurnal Skolastik Keperawatan ISSN : 2443-0935, E-ISSN 24431699. 4 (1), 7381.https: / / jurnal.unai.edu/in dex.php/jsk/article/download /735/596/2127.

Galuh.(2017).Faktor-faktor yang Mempengaruhi Kejadian Demam Tifoid Pada Anak. Fakultas Kedokteran Universitas Muhammadiyah Semarang.1-8. 
http://download.garuda.riste dikti.go.id

Kemenkes RI.(2018). Balai tehnik Kesehatan Lingkungan dan Pengendalian Penyakit (BTKLPP) Kelas I Medan

Lestari,T. (2016). Asuhan Keperawatan Anak. Yogyakarta : Nuha Medika.

Maryustiana, dkk.(2019). Efektifitas Penurunan Suhu Tubuh Menggunakan Kompres Hangat Dan Water Tepid Sponge. Holistic Jurnal Kesehatan. 13 (2).143-153

https://www.researchgate.ne $\mathrm{t}$

Ni dan Diah.(2017). Karakteristik Usia, Jenis Kelamin, Tingkat Demam, Kadar Hemoglobin, Leukosit Dan Trombosit Penderita Demam Tifoid Pada Pasien Anak. Jurnal Ilmiah Kedokteran, 4 (2).30-40 http://jurnal.untad.ac.id/jur nal/index.php/MedikaTadulak o/article/download/9285/737 6.

Pangaribuan, Resmi. (2018). Kebutuhan Dasar Manusia.

Pangaribuan, R., \& Marliani, M. (2020). Hubungan Pengetahuan Ibu Tentang Pola Makanan Balita Dengan Status Gizi Balita di Rumah Sakit TK. II Putri Hijau Medan. Journal of Health Science and Physiotherapy, 2(2), 123-133. https://doi.org/10.35893/jhsp .v2i 2.47

Riyadi,S\&Suharsono.(2010). Asuhan Keperawatan Pada Anak Sakit. Yogyakarta : Gosyen Publishing.

Tarwoto, \&Wartonah. (2010). Kebutuhan Dasar Manusia Dan Proses Keperawatan. Jakarta : Salemba Medika.
WHO.(2018).Thypoid And Other Invasive

Salmonellosis.https://www.w ho.int/mediacentre/factsheet s/typhoid/en/.

Yatnita. (2011). Bakteri Salmonella Typhi Dan demam tifoid. Jurnal Kesehatan Masyarakat, September 2011-Maret 2011, 6 (1). $42-46$ fkm.unand.ac.id/ index.php/jkma /article/view/87

Zurimi, Suarmi. (2019).Pengaruh Pemberian Kompres Hangat Dalam Pemenuhan Ketidakefektifan Termogulasi Pada Pasien Demam Thypoid.Global Health Science ISSN 2503-5088 (p) 2622-1055 $\begin{array}{lll}\text { (e), } 4 & 4 & \text { (3).131-136 }\end{array}$ https://jurnal.csdforum.com/ index.php/GHS/article/view/g hs4307. 